\title{
SPECT を使った脳機能画像の定量化と標準化
}

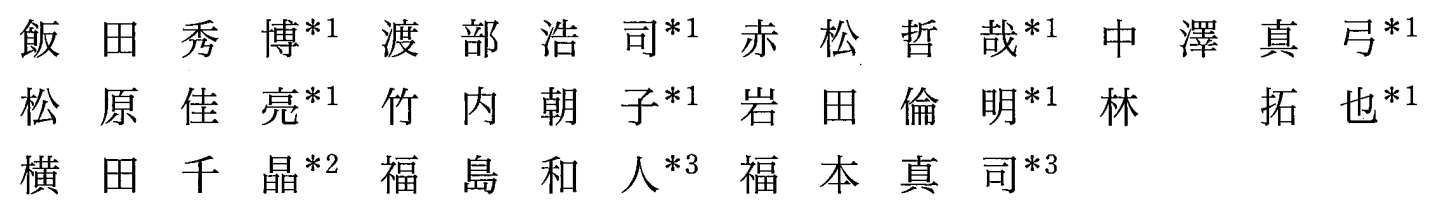

The Validity and Value of a Quantitative SPECT Reconstruction Package (QSPECT) for evaluating Multi-center Clinical Trials

by

Hidehiro Iida, D.Sc., Ph.D. ${ }^{* 1}$, Hiroshi Watabe, Ph.D. ${ }^{* 1}$, Tetsuya Akamatsu, B.Sc. ${ }^{* 1}$, Mayumi Nakazawa, M.Sc. ${ }^{* 1}$, Keisuke Matsubara, M.Sc. ${ }^{* 1}$, Asako Takeuchi, M.Sc. ${ }^{* 1}$, Michiaki Iwata, M.Sc. ${ }^{* 1}$, Takuya Hayashi, M.D., Ph.D. ${ }^{* 1}$, Chiaki Yokota, M.D., Ph.D. ${ }^{* 2}$, Kazuto Fukushima, M.D., Ph.D. ${ }^{* 3}$, and Shinji Fukumoto, B.Sc. ${ }^{* 3}$

from

${ }^{*}$ Department of Investigative Radiology, National Cardiovascular Center Research Institute,

${ }^{*}$ Department of Cerebrovascular Medicine, National Cardiovascular Center Hospital, and

${ }^{* 3}$ Department of Radiology, National Cardiovascular Center Hospital

SPECT has the potential to provide parametric functional images, in a "quantitative"manner, for several radiotracers in vivo, as has been widely done with PET. Due to the ready availability of SPECT, in addition to the wellestablished delivery/transportation of various radio-ligands, SPECT has an advantage for large-scale clinical evaluation. It has, however, been considered that the accuracy and inter-institutional reproducibility of SPECT are not well verified, which is largely attributed to a lack of general consensus of reconstruction procedures (attenuation/scatter correction). We have recently developed a novel method to reconstruct SPECT images from existing projection data including appropriate corrections for scatter and attenuation in the object. We have demonstrated that this program is capable of providing accurate radio-distribution in the brain and thorax regions, and also restDiamox CBF using split-dose ${ }^{123} \mathrm{I}$ amphetamine (IMP). Various phantom experiments also supported the validity of inter-institutional reproducibility. These data suggested that QSPECT could be a useful tool for quantitative mapping in clinical research, allowing for large scale clinical evaluations even when using SPECT cameras from different manufacturers.

(Received July 7, 2007； accepted July 11, 2007)

Key words : SPECT, cerebral infarction, cerebral blood flow reserve, quantitative Jpn J Neurosurg（Tokyo） $16: 742-752,2007$

はじめに

SPECT は, PET と同様に種々の生体機能をイメージ
ングすることができ，循環器系疾患の診断を中心に，臨 床医学において重要な役割を担ってきた。組織血流, 基 質代謝，神経受容体のイメージング，さらに近年では遺

\footnotetext{
*1国立循環器病センター研究所先進医工学センター放射線医学部 $/ 7565-8565$ 吹田市藤白台 5-7-1〔連絡先：飯田秀博〕 Address reprint requests to: Hidehiro Iida, D.Sc., Ph.D. Department of Investigative Radiology, National Cardiovascular Center Research Institute, 5-7-1 Fujishiro-dai, Suita-shi, Osaka 565-8565, Japan

*2国立循環器病センター病院脳血管内科, *3国立循環器病センター病院放射線診療部
} 


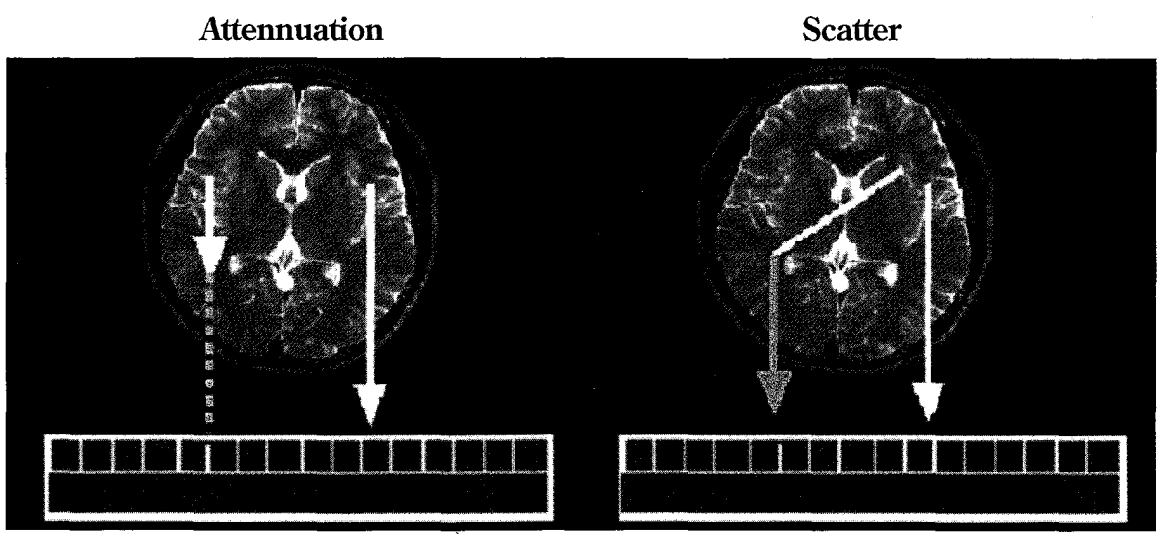

$\underline{\mathbf{A} \mid \mathbf{B}}$

Detector

Detector

Fig. 1 Two important source of errors, namely the photon attenuation (A) and the Compton scatter (B).

伝子発現や，蛋白やペプチドの動態イメージングも可能 になりつつある。臨床施設に扮ける SPECT の沉用性は 高く, また多くの診断放射性薬剤の流通が確立している ことから，多くの臨床研究にも応用されている．PETを 使った創薬支援が議論される中，大規模な臨床評価試験 での SPECTの貢献が期待される。しかし現時点では SPECT 画像の定量性は必ずしも保障されておらず,施設 を超えた再現性は確保できていないとされる4)。これは, 機器ごとに画像を再構成する手法や散乱線や吸収補正を 行う手技が統一化されておらず，現実には操作者の技術 に依存すること，加えて装置のクオリティコントロール （QC）が未成熟であり，機器メーカー間で異なることが 原因であった。

定量的な SPECT 画像再構成においては多くの数学的 手法が提案され，また散乱線を補正する方法についても 多くの論文報告がなされてきた、最新の技術を用いると， 上記 2 つ補正は十分に正確に行うことができ, PET に 匹敵する精度での画像提示が可能であると考えられてい る。われわれは，これらの技術を結集して沉用的な SPECT 画像再構成パッケージ (QSPECT) の開発に着手 し, Windows コンピュータで実行できるプログラム群を 開発した。これに基づいて SPECT 診断の精度向上, 検 查と解析にかかるプロトコルの最適化と標準化を目指す ものである.SPECT 装置を使った機能画像診断における 施設間誤差を最小限にすることで, 今までにない生体機 能イメージングの客観的評価基準の確立が可能であると 考える ${ }^{89911)}$ 。また，このような定量計測で得られた SPECT 画像に対してコンパートメント数理モデル解析 を適用することで，1回の検査で安静時および血管拡張 時の複数の局所脳血流量の画像撮像も可能になった ${ }^{13)}$. この方法に基づき, 血行力学的脳虚血診断検査への応用
が可能になった。

本稿では, QSPECT 画像再構成と血行力学的脳虚血診 断検査のそれぞれの理論背景, 撮像と画像解析にかかる 基盤技術を概説し, 機能画像の定量解析の意義と妥当性 について議論する，施設を超えた再現性を確保するため の課題についても述べる.

\section{定量的な SPECT 画像再構成法}

一般的な臨床脳 SPECT 検査では，60～80\%の光子が 体内で吸収を受け，30４0\%の光子が散乱によって偽り の信号を与えている (Fig. 1). 脳 SPECT 検査では, ほ ぼすべての装置で吸収補正がなされるようになってい る.しかし頭部輪郭抽出法などの補正における詳細な手 技は必ずしも統一化されておらず，例えば頭蓋の輪郭抽 出の方法や精度, また吸収減弱係数は, ユーザーが任意 な数值を設定するような仕様が通常である，散乱線補正 については, 手法そのものが機種ごとに異なり, 装置に よっては補正を行わない場合もある。この場合には，吸 収減弱係数としては理論的な数值に固定するのではな く, ユーザーが任意な数值を設定することでアーチファ クトの除去あるいは軽減を推奨している。したがって画 像再構成に必要なパラメー夕数值の選択は, 各機関の技 師などの判断に基づいて行われ，本来は画質改善や補正 の精度向上を目的にするものであるが，しかし施設間誤 差の要因になっていることは明らかである。結果として 画像のコントラストは装置メーカーや機種によって異な り, またさらに機種ごとに異なる画像の表示法（カラー スケールなど）も，装置を超えた再現性を確保すること を難しくしている，近年，欧州にてなされた多施設評価 研究では, SPECT 画像の施設間誤差は予想以上に大き 


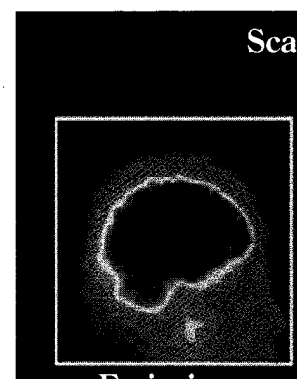

Emission Projection
Scatter Estimation by Use of Transmission
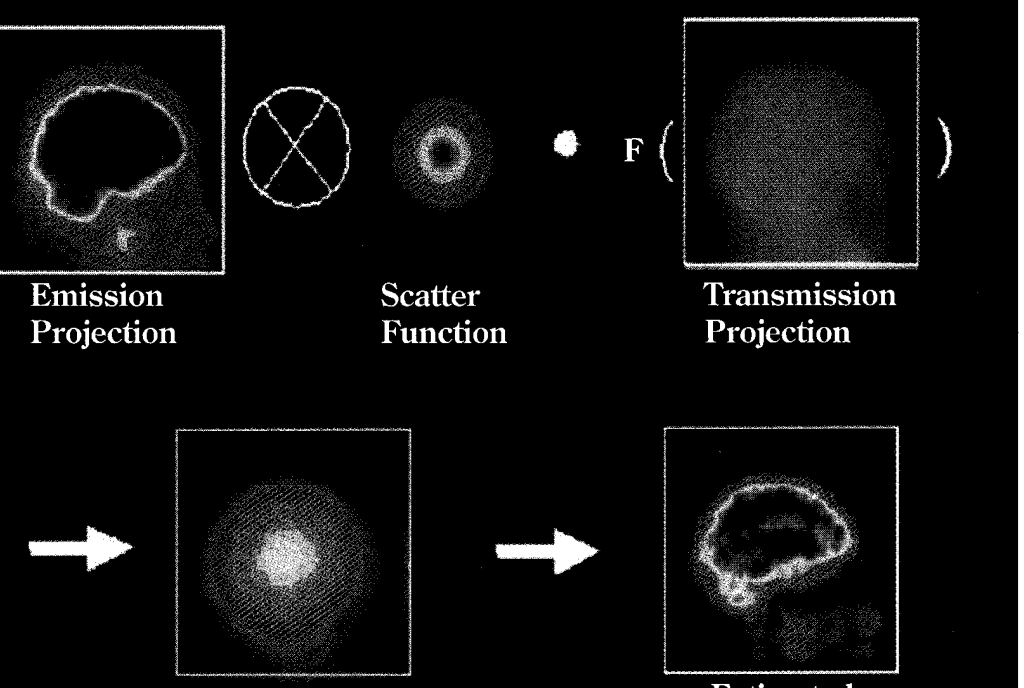

Estimated

Scatter

Projection

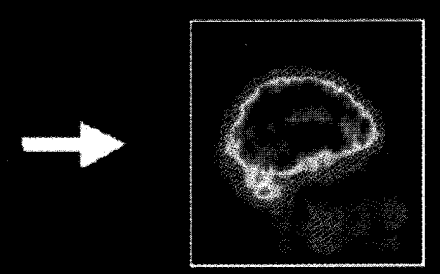

Estimated

Primary Projection

Fig. 2 Schematic diagram of the transmission-dependent convolution subtraction (TDCS) method implemented in the QSPECT program for scatter correction. Geometric means of emission projections were first convolved with an empirically determined scatter function, and were scaled pixel-bypixel using an empirically defined relation between the scatter fraction and attenuation factor. Transmission projections were generated from a constant $\mu$ map in the object. The inverse of the transmission projection is displayed in the figure.

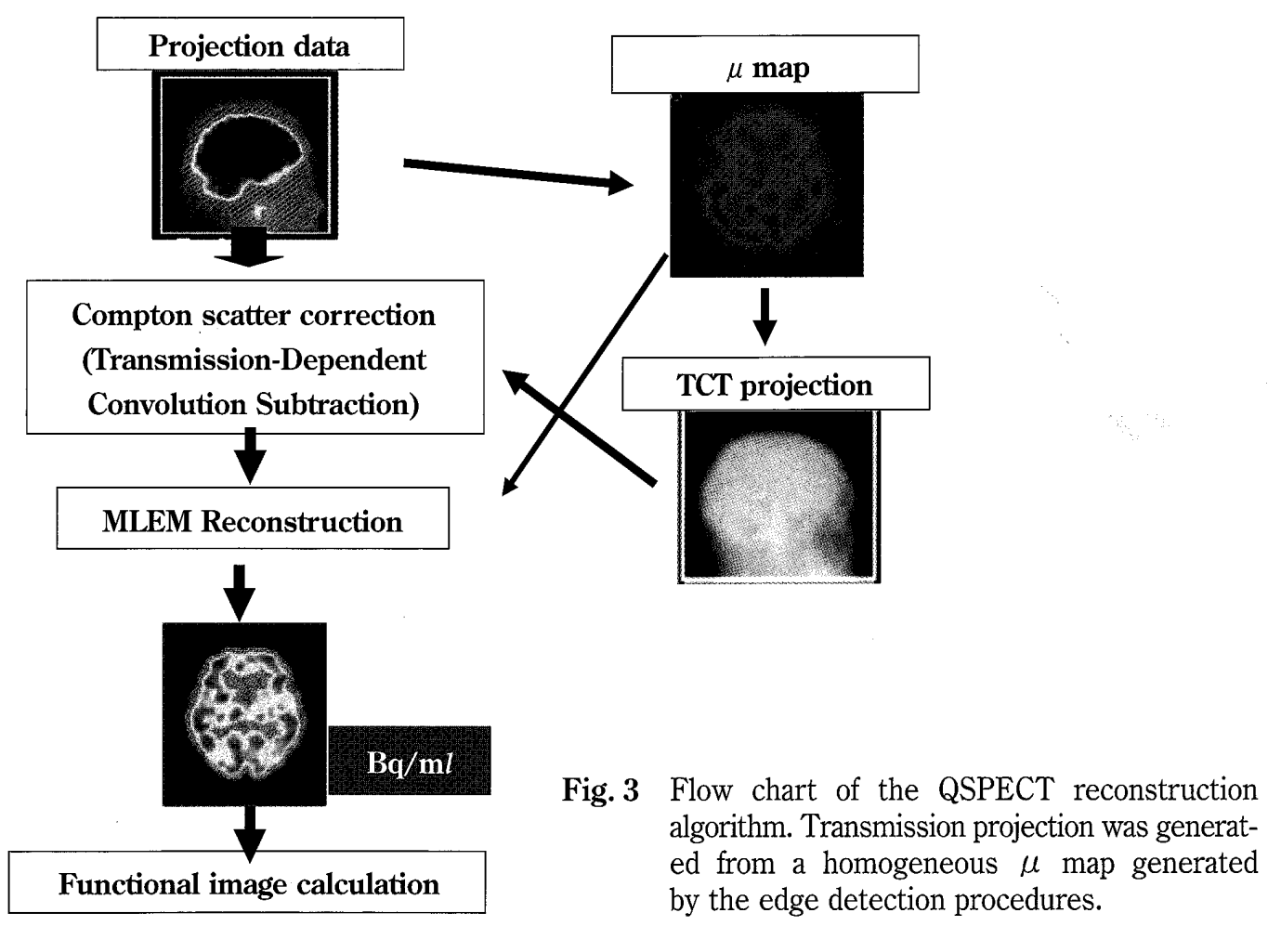

く, 多施設臨床研究は困難（神話）であるとの見解が報 告れさた ${ }^{4)}$. 具体的には, 数值的に計算された共通のプ ロジェクションデータを, フランス国内の 6 つの施設に おいて 12 の異なる画像再構成プログラムによって画像 計算し, 画像の絶対值およびコントラストが比較された。 結果は, 施設および装置, また画像処理プログラムに依
存して大きく異なっており，施設を超えた再現性を確保 するためには，標準化に向けた本質的な技術開発の必要 があることが確認されたところである。

SPECT における光子の吸収は重要な補正要素である にもかかわらず，厳密（解析的）な補正法はまだ発見さ れていない。このために SPECT を使った定量は不可能 


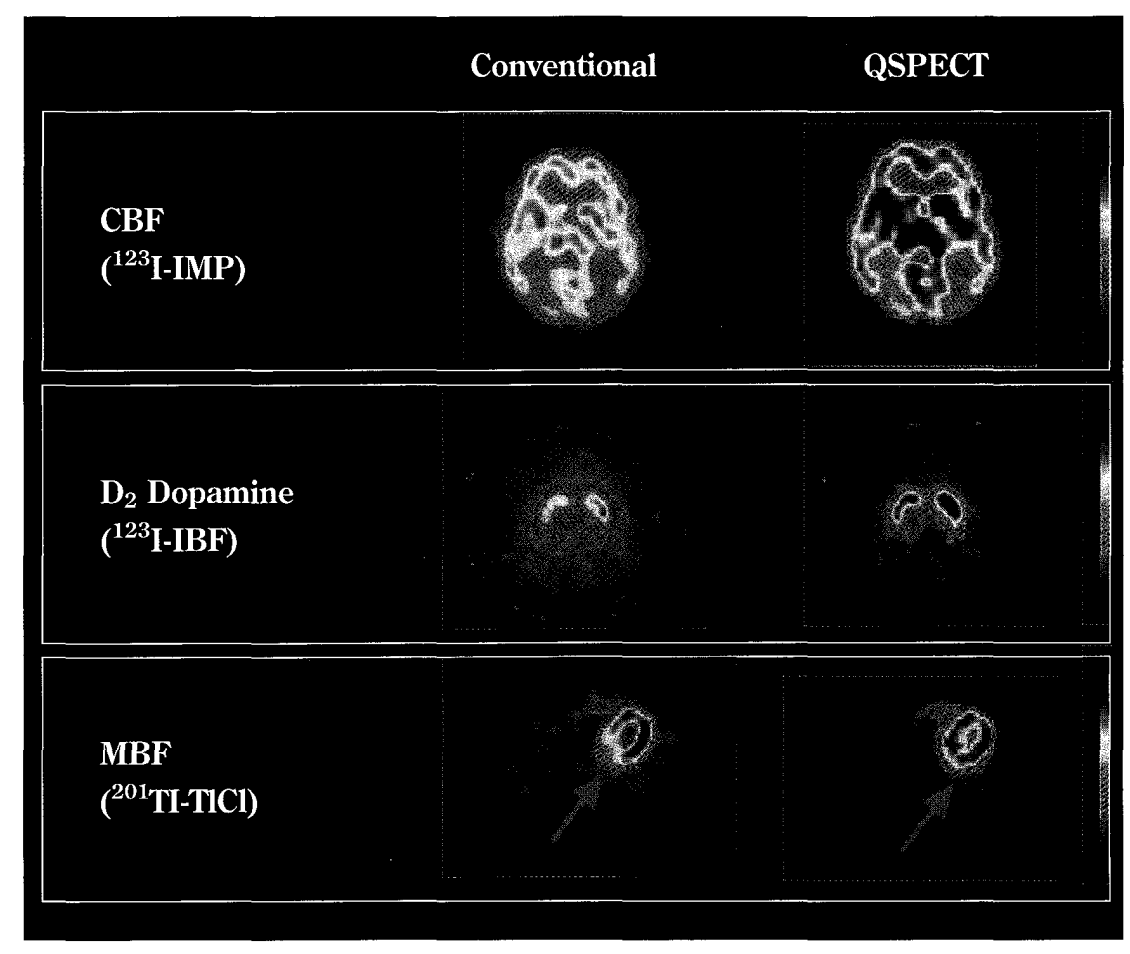

Fig. 4 Comparison of SPECT images obtained from typical clinical studies. Left images were calculated by conventional programs without scatter correction for the brain, and without scatter or attenuation correction for the myocardium.

であるとの極論もあったＰETの場合には外部線源など で得たデー夕を使って単純な処理で正確に補正できる が，この手法はSPECTには適用できない。これは放射 線信号の受ける吸収が深さに依存して変化するためであ る. 数值的な逐次近似に基づく再構成法において, 吸収 減弱のプロセスを計算に組み込むことで必要十分な精度 での補正が可能となった，仮想した画像分布から吸收減 弱を含むプロジェクションデータを推定し，最无法 (MLEM 法) と呼ばれる統計学に基づくアルゴリズムで 逐次, 真の画像に収束させていくものである. SPECT を 使った定量診断にとってはきわめて重要な進歩であり, このアルゴリズムの登場によって SPECT での定量評価 が初めて確実なものになった. MLEM 法に抢ける逐次近 似の収束性は理論的に保証されており，かつ正確に吸収 補正さ机た画像が得られる。またさらに収束速度の高速 化法も確立し, 結果として従来の方法と比べてほぼ同程 度の計算時間で正確な画像が得られるようになった。

QSPECT においてもこの方法を採用している.

もう一つの誤差要因である散乱線については，多くの 方法が提案されてきたにもかかわらず，臨床デー夕に適 用された事例はきわめて少ない。吸収補正法が十分に確 立されていなかったがために散乱線補正法の厳密な評価 ができなかったこと，加えて補正による統計ノイズの上 昇（画質の劣化）が大きくて実用に耐えられなかったこ とが主な理由である，QSPECT プログラムでは，吸収補 正に利用するための吸収減弱デー夕を使って散乱線分布
を推定・補正する transmission-dependent convolusion subtraction (TDCS 法) ${ }^{10) 18) \sim 20)}$ と呼ばれる方法を採用している. 補正に必要なパラメー夕は，系統的かつ理論的・実験的 な検討によって最適化したことで十分に高い精度が確保 でき10)18) 20)，また画質の劣化がほとんどないことも確 認できたので，既存の散乱線補正法としては最も実用的 かつ精度の高いものとなった ${ }^{8) 913)} .{ }^{99 \mathrm{~m}} \mathrm{Tc},{ }^{123} \mathrm{I},{ }^{201} \mathrm{Tl}$ などすべての SPECT 製剤に利用できる利点もある，F ig.2 に示すように, ${ }^{123} \mathrm{I}-\mathrm{IMP}$ の臨床に掞いても，画像ノ イズをほとんど上昇させずに散乱線補正を行うことがで きる ${ }^{8) 1019) 20)}$. 脳 SPECT 検査においては, 頭部の吸収減 弱分布はエミッションのプロジェクションデータの輪郭 抽出によって計算することができる. QSPECT における 画像再構成アルゴリズムは，脳だけでなく心笳などの体 幹部の検査にも応用でき，現存する実用的な SPECT 画 像再構成プログラムの中で最も実用的かつ精度の高いプ ログラムであると考光られる。このプログラムの流れを Fig. 3 に示す.

Fig. 4 には, QSPECT 画像再構成の結果と, 散乱線補 正を行わない従来法によるものとの比較を示す．IMPを 使った脳血流量の定量診断においては, 散乱線補正に よって画像のコントラストが上昇する。また今までの研 究では, 散乱線の影響は脳内部位によって異なり, 脳血 流量値は，脳皮質領域では $20 \%$ 程度の上昇，小脳では $30 \%$ 程度の上昇, 深部灰白質領域では 5 $10 \%$ 程度の上 昇, 半卵円中心領域では逆に $30 \%$ 程度の減少することが 


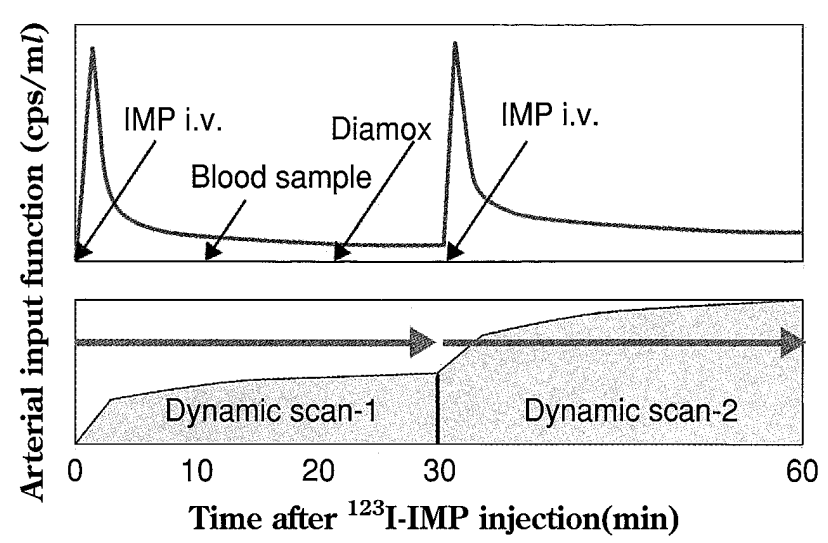

Fig. 5 Schematic diagram of the dual-table ARG protocol for assessing two regional $\mathrm{CBF}$ images, at rest and after acetazolamide. IMP is intravenously injected twice, once at the time of SPECT scan $(\mathrm{t}=0 \mathrm{~min})$ and again at approximately $30 \mathrm{~min}$. Arterial blood is sampled at approximately $10 \mathrm{~min}$, for calibrating the standardized arterial input function. Acetazolamide is administered at approximately $10 \mathrm{~min}$ before the second IMP administration.

報告されている ${ }^{8)} . \mathrm{D}_{2}$ ドーパミン受容体リガンドである ${ }^{123} \mathrm{I}$ 標識 IBF の画像においても, 散乱線補正は画像のコント ラスト上昇に寄与しており, 線状体領域での集積率の上 昇, 参照領域である小脳〜後頭葉での低下（散乱線成分 の除去）が明白である，心筋 ${ }^{201} \mathrm{Tl}$ においては，従来法で は散乱線のみならず吸収補正も行っていないため，放射 性薬剤の集積は不均一である。特に後壁における欠損が 認められる。吸收補正および散乱線補正を含む QSPECT 画像再構成ではほぼ一様な集積画像を得ることができた とおり, 当該研究グループだけでない多くの検討によっ て正確な画像提示の妥当性が確認されてい $ろ^{1(\sim 3) 8)(10) 14) \sim 17)}$.

\section{局所脳血流量と血流予備能の計測理論と 必要条件}

脳内の放射性薬㓮の分布が正確に計測できることは, PET で広く行われているようなコンパートメントモデ ルに代表される数理モデル解析と機能画像の定量評価が 可能になったことを意味する。脳血流製剤の複数回投与 をして行うSPECT 検查に, 数理動態モデルを適用する ことで, 1 回の検査のみで安静時と血管反応性の診断評 価をすることが可能になった ${ }^{8)}$ (Fig. 5). Dual-table ARG 法と呼ばれる方法では, 2 回目の IMP 投与に同期させて 2 度のダイナミック SPECT スキャンを行う. 2 回目 IMP
投与のおよそ10 分前に血管拡張薬 (acetazolamide) を投 与することで, 2 度目のスキャン画像から血管拡張時の 局所脳血流量画像が得られる。安静時および血管拡張時 の一連の画像デー夕に対してコンパートメントモデルを 適用し, 安静時と血管拡張時の局所脳血流量の定量画像 を計算する。この方法では, 被験者が SPECT 装置内で 横になっている間に得られるすべての放射線信号を解析 に利用する。また単純な減算処理を行なわず，一連の画 像に動態解析理論を適用することで画像ノイズの上昇を 抑制しているので最善の画質が得られる。高い精度で, 安静時および負荷後の局所脳血流量画像を得ることがで きる方法は, 血行力学的な脳虚血の重症度診断に有効で ある.Fig. 6 には本方法で得た典型的な 2 つの症例の結 果を示す，ともに内頸動脈閉塞症であるが顕著な脳梗塞 は認めない症例であり, 上図では安静時において左右差 ないが血管反応性の低下を認め, 軽度のリスクを有する ことを示唆する。一方, 下図では安静時に低下かつ血管 反応性が消失しており，高度のリスクを有することを示 唆する.また Fig. 7 に示すような PET との比較検討にお いても, 安静時および血管拡張時の局所脳血流量画像は, 絶対値および画像コントラストはPET に一致する診断 情報となっていることが確認されている8)。このような 血行力学的脳虚血の診断情報は, 頭蓋内血管バイパス術 を含む血行再建術の適応を判定するなどで有効利用でき ることが期待される。

このような血管拡張能の画像診断においては，高い血 流量領域まで定量計測できる診断薬剤を利用することが 重要である。 ${ }^{123} \mathrm{I}$ 標識ヨードアンフェタミン (IMP) は脳 内への取り込久率が高く ${ }^{7)}$, 実際に ${ }^{15} \mathrm{O}$ 標識水に匹敵する 初回循環移行率を有するので, 血管拡張薬を投与した後 の局所血流量および血管反応性（あるいは血流予備能） の検査に利用することができる.SPECT 検査用の脳血流 量製羭としては ${ }^{99 \mathrm{~m}} \mathrm{Tc}$ 標識薬剤もあるが, 高血流量領域 では集積率が飽和する傾向にあることが知られており， したがって血管反応性の定量評価には適していないと考 えられる。慎重な検討が望まれる12).

1 回の検査において局所脳血流量画像を複数計測する ためには，検査途中で血流量を変化させる必要がある． これは従来の数理モデル解析における大前提とされてい る「生理パラメータは計測中に普遍である」という仮定 に矛盾するものである。当該研究グループでは, 過渡的 な重み関数の概念を導入してこれが問題にならないこと を突き止めた。すなわち，第 1 スキャン中の後半に局所 脳血流量が変化しても，1回目のスキャンから計測され る脳血流量值はほぼ初期の数分間の平均值を示すもので 
Rest-Diamox CBF images in pt with moderate risk

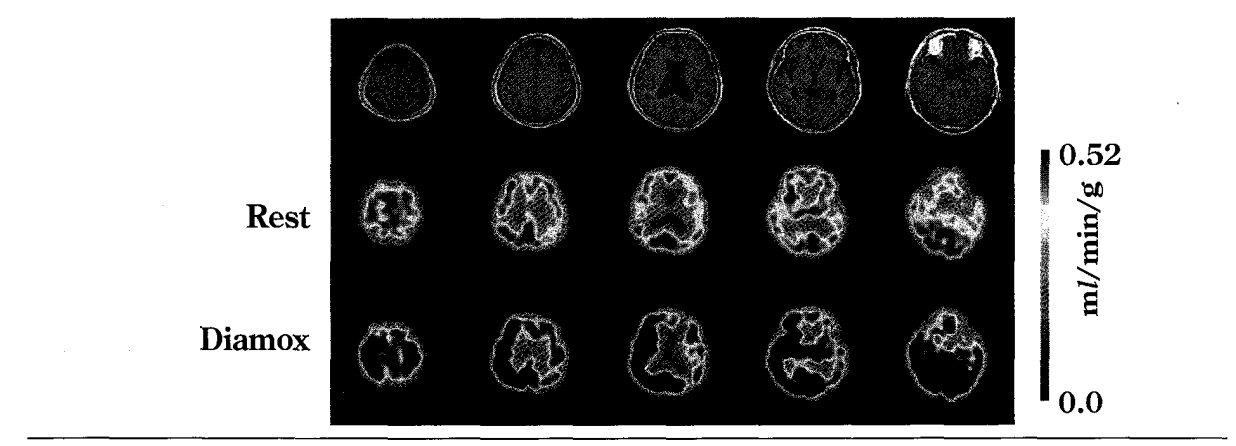

Rest-Diamox CBF images in pt with high risk

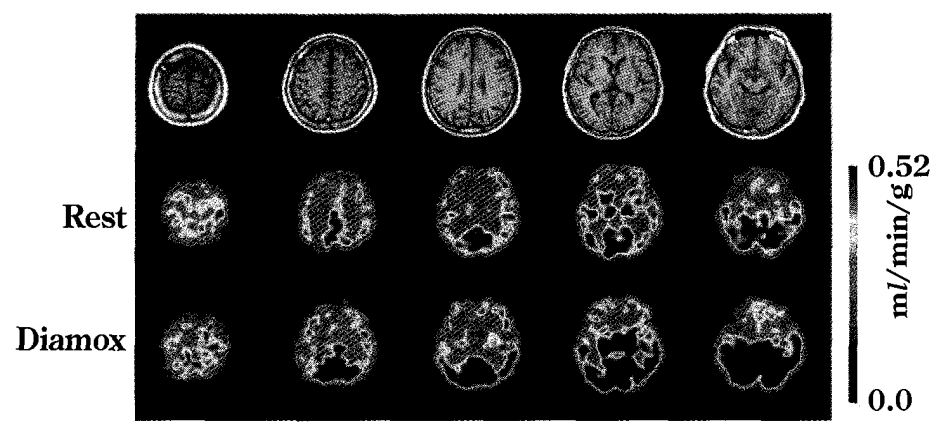

Fig. 6 Typical examples of CBF images at rest and after acetazolamide by the dual-table ARG method with the QSPECT reconstruction. Two patients had MCA occlusion. The upper case indicated reduced flow reactivity after acetazolamide, but normal $\mathrm{CBF}$ at rest. The Lower case indicated reduced $\mathrm{CBF}$ at rest, and reduced $\mathrm{CBF}$ reactivity after acetazolamide.

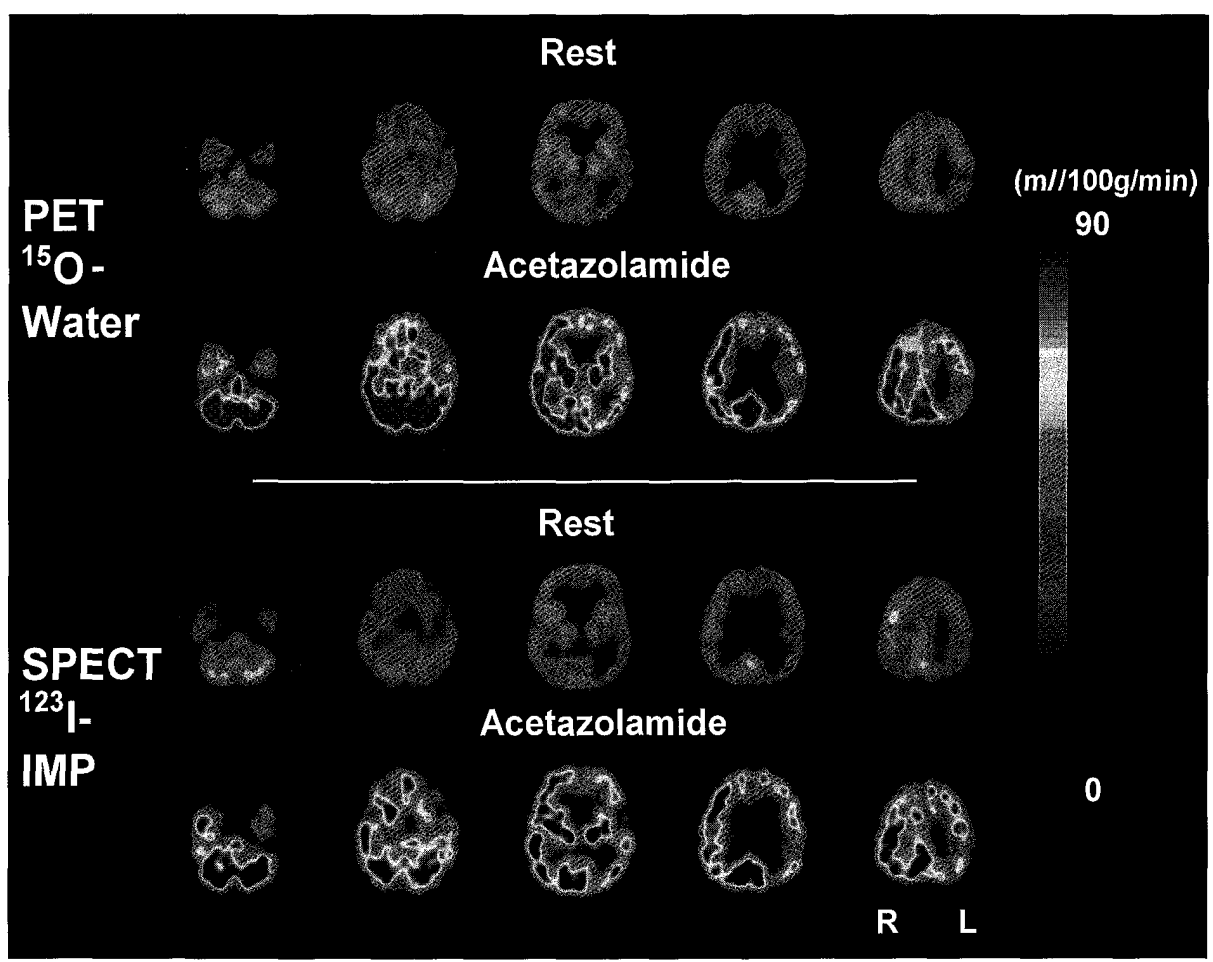

Fig. 7 Comparison of $\mathrm{CBF}$ images at rest and after acetazolamide administration obtained with dual-table ARG and QSPECT programs with those obtained with ${ }^{15} \mathrm{O}$ PET. Good agreement in image contrast and absolute values are visible. 
A $\underset{\mathrm{k}_{2}}{\stackrel{\mathrm{K}_{1}}{\rightleftarrows} \mathrm{C}_{\mathrm{ND}}\left(=\mathrm{C}_{\mathrm{FT}}+\mathrm{C}_{\mathrm{NS}}\right) \underset{\mathrm{k}_{4}}{\stackrel{\mathrm{k}_{3}}{\rightleftarrows} \mathrm{C}_{\mathrm{S}}}} \begin{aligned} & \mathrm{BP}_{\mathrm{S}} \propto \mathrm{k}_{3} / \mathrm{k}_{4} \\ & \mathrm{f}_{\mathrm{ND}}=\mathrm{C}_{\mathrm{FT}} / \mathrm{C}_{\mathrm{ND}}\end{aligned}$

$$
\begin{gathered}
\underset{\mathrm{C}}{\stackrel{\mathrm{K}_{1}}{\rightleftarrows}} \mathrm{C}_{\mathrm{T}}\left(=\mathrm{C}_{\mathrm{ND}}+\mathrm{C}_{\mathrm{S}}\right) \\
\mathrm{k}_{2} \\
\mathrm{~V}_{\mathrm{T}}=\mathrm{K}_{1} / \mathrm{k}_{2}
\end{gathered}
$$

B
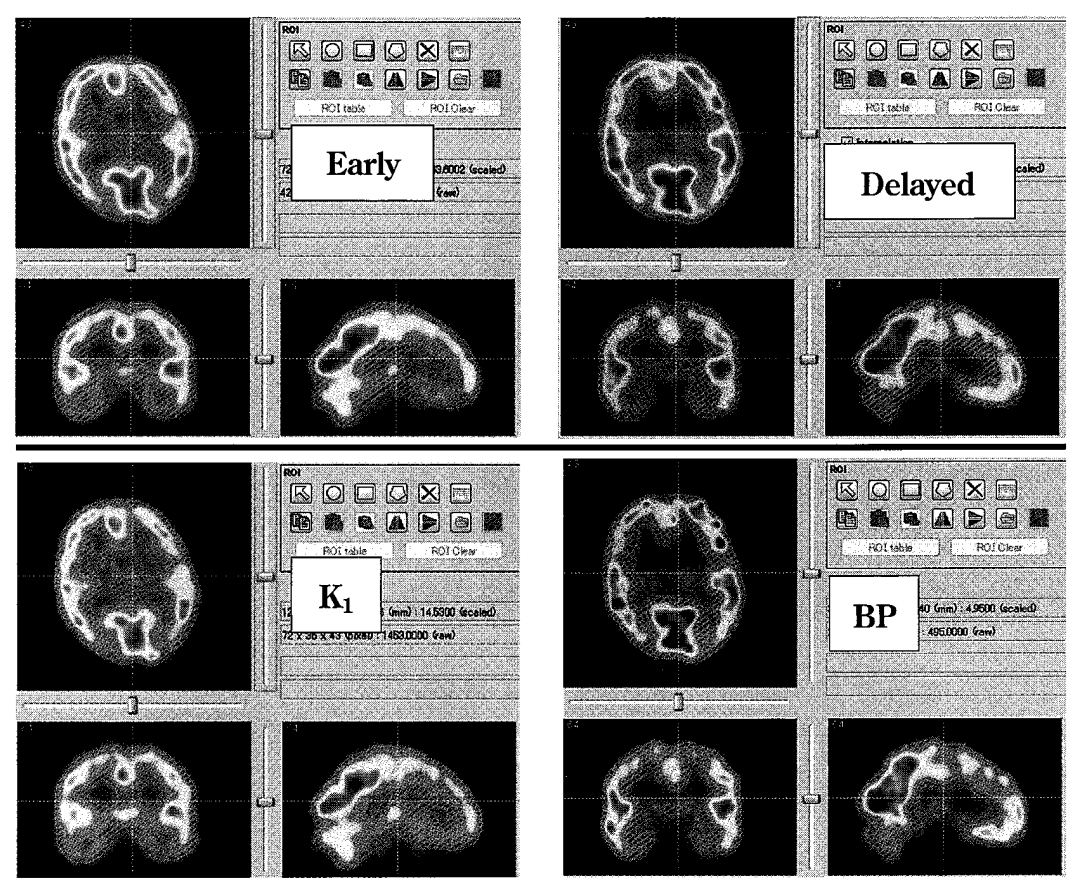

Fig. 8 A: A compartment model for the benzodiazepine ligand, I-123 Iomazenil (IMZ). See text for details.

B : Example images of IMZ obtained from a healthy volunteer. Original early and delayed images and functional $K_{1}$ and Binding-Potential (BP) images calculated by assuming the model in Fig. $\mathbf{8 A}$ are shown.
あり，後半の変化の影響は無視できるほど小さい．また 第 2 回目のスキャンが提示する脳血流量画像も, 2 回目 の IMP 投与の前に血流量が変化しているかぎり正確に 2 回目投与後数分間の脳血流量值を反映する. 2 回目の スキャン中の血流が変化してもこの影響は反映されない ことが明らかになった。詳細はわれわれの過去の論文を 参照されたい5).

\section{ベンゾジアゼピン受容体結合能の イメージング}

定量的な SPECT 画像が得られるようになって, 種々 の神経受容体の機能画像の定量評価も可能になる. ${ }^{123} \mathrm{I}$ 標識イオマゼニル (IMZ) は脳の抑制系と密接に関連 する中枢性ベンゾジアゼピン受容体と選択的に結合し， その脳内分布は神経細胞の残存に深く関係している。脳 虚血性疾患の画像診断においては，血流が低下している 部位の神経細胞の残存の程度を評価することができるこ とが示唆されており, 上記血行力学的脳虚血のより詳細 な病態診断への期待が高まっている. IMZ は高い割合で
脳内に集積するので初期画像は比較的脳血流量画像に一 致する分布を示すが, 時間とともに神経細胞の残存に比 例した分布を示すようになる。十分時間が経過すると(3 時間程度）画像は基本的に神経残存を示すものである. ただし血流量が低下している領域では脳への集積率が低 く, 神経残存を過小評価する傾向にある. 定量的な画像 が得られることで，コンパートメントモデルを適用する ことが可能になるので，イオマゼニール薬剤の受容体へ の結合能 (binding potential; BP) を数理的に計算するこ とができる.

IMZ の脳内動態を表すコンパートメントモデルを Fig. 8A に示す. 同図上では, 血漿中の IMZ は毛細血管移行 速度定数 $\left(\mathrm{K}_{1}\right)$ に比例して脳内に移行し, 組織中の自由 $\left(\mathrm{C}_{\mathrm{FT}}\right)$ および非特異的結合している $\left(\mathrm{C}_{\mathrm{ND}}\right)$ 分画は逆の 速度定数 $\left(\mathrm{k}_{2}\right)$ に比例して洗い出されるモデルが示され る. 特異的に結合している分画との移行速度定数の比 $\left(\mathrm{k}_{3} / \mathrm{k}_{4}\right)$ が結合能を示すとされる.このモデルはさらに 単純化することができ, 同図下に示すように血漿中の濃 度 $\left(\mathrm{C}_{\mathrm{p}}\right)$ と組織中の濃度 $\left(\mathrm{C}_{\mathrm{T}}\right)$ との相互移行で記述する. この場合には平行時のトレーサ濃度比により分布体積 
A
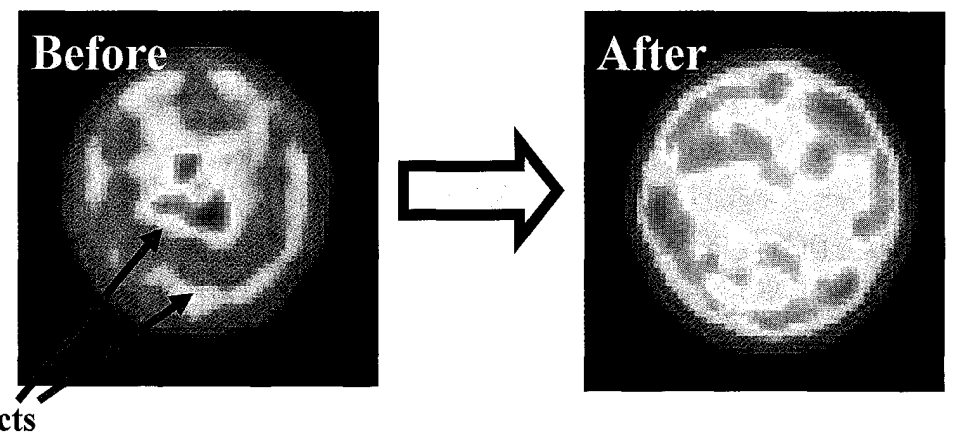

Artifacts

B

NAI Scintilation counter

Plastic scintilator
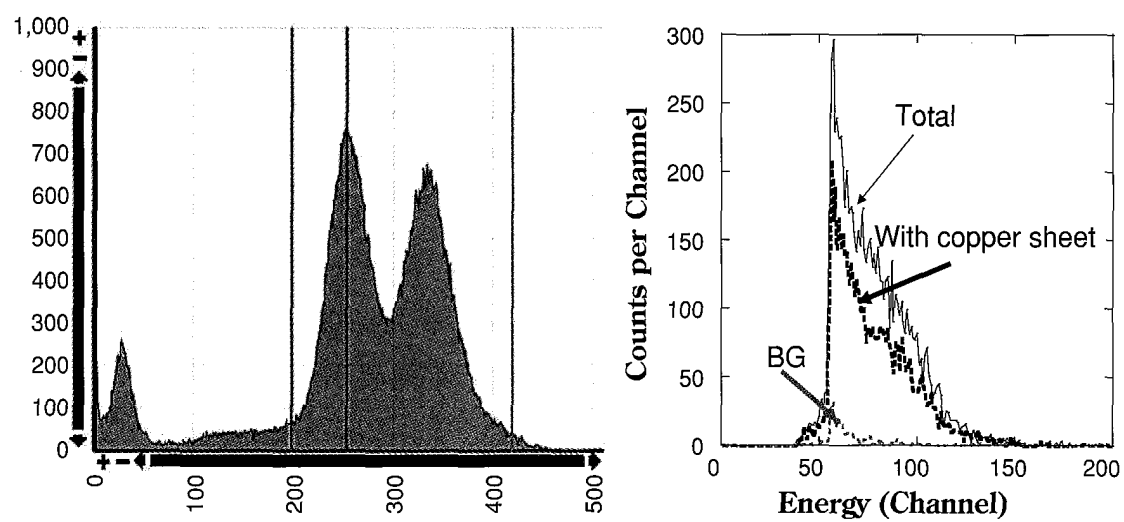

Fig. 9 A : Filled with I-123 solution. Images can be degraded when homogeneity correction is insufficient as shown on the left. This can be fixed after applying quality control. One way to confirm the quality control is to view these phantom images.

B : Energy spectra obtained from two typical detector systems. NaI detector normally display two peaks, for which energy windows to cover both peaks are recommended. In case of a plastic scintilator, peaks are not visible, and thus careful attention is needed.

（VT）が定義でき，これと結合能との関係は次式で表せ る.

$$
\frac{C_{t}\left(t_{\mathrm{e}}\right)}{C_{t}\left(t_{\mathrm{d}}\right)}=\frac{C_{p}\left(t_{1}\right) \otimes e^{-\mathrm{k}_{2} t_{\mathrm{e}}}}{C_{p}\left(t_{2}\right) \otimes e^{-\mathrm{k}_{2} t_{\mathrm{d}}}}
$$

$$
V_{T}=f_{P}\left(\frac{1}{f_{N D}}+\frac{B_{\text {avail }}}{K_{d}}\right)
$$

よって IMZ の実行的な結合能 BP (すなわち $\mathrm{B}_{\text {avail }} / \mathrm{K}_{\mathrm{d}}$ ) はおよそ

$$
\mathrm{BP} \fallingdotseq \mathrm{V}_{\mathrm{T}}-1
$$

で求めることができる。つまり十分に $V_{\mathrm{T}}$ が大きいとき には BP はほぼ $\mathrm{V}_{\mathrm{T}}$ に一致する。

また, Fig. 8A 下図のようなコンパートメントモデルに 対しては, early スキャン, delayed スキャンそれぞれの 時刻において次式が成り立つ.

$$
\begin{aligned}
& C_{t}\left(t_{\mathrm{e}}\right)=K_{1} C_{p}\left(t_{\mathrm{e}}\right) \otimes e^{-\mathrm{k}_{2} t_{\mathrm{e}}} \\
& C_{t}\left(t_{\mathrm{d}}\right)=K_{1} C_{p}\left(t_{\mathrm{d}}\right) \otimes e^{-\mathrm{k}_{2} t_{\mathrm{d}}}
\end{aligned}
$$

両辺を除すと
を得る.この式により, early 画像と delayed 画像のそ れぞれの画素值の比が， $\mathrm{K}_{1}$ には無関係となり， $\mathrm{k}_{2}$ のみ 関数として記述できることがわかる，すなわち，あらか じめ (4) 式により 2 つの画像の画素值の比を $\mathrm{k}_{2}$ を変化 させて表として計算しておけば，実際の画像の画素值の 比から一意に $\mathrm{k}_{2}$ の画像を計算することができる6). いつ たん $\mathrm{k}_{2}$ 値が得られれば，画素ごとに

$$
K_{1}=\frac{C_{t}\left(t_{\mathrm{e}}\right)}{C_{p}\left(t_{\mathrm{e}}\right) \otimes e-k_{2} t_{\mathrm{e}}}
$$

により $\mathrm{K}_{1}$ 值を，すなわち $\mathrm{K}_{1}$ 画像を計算することがで きる。これらの画像から $\mathrm{V}_{\mathrm{T}}$ 画像を $\mathrm{k}_{2} / \mathrm{K}_{1}$ として, および BP 画像を（2）式に基づいて計算することができる.

健常者に扮ける IMZ の early 画像と delayed 画像, お よび本計算法で得た $\mathrm{K}_{1}$ 画像と $\mathrm{BP}$ 画像の例を Fig. 8B に 
示す.健常者の画像であるので delayed 画像と BP 画像は 類似しているが，今後虚血性疾患における検討，特に血 流量が低下している領域での診断が期待される。

従来は安静時の脳血流イメージだけであった SPECT において，1回の検査のみで血管反応性の定量評価がで きるようになり，さらに神経受容体イメージに基づく残 存神経細胞の空間的広がりと結合能に関して定量的な情 報が得られるようになった。すでにてんかんなどへの臨 床診断に利用されているが, さらに虚血性疾患への貢献 について高い期待が寄せられる。

\section{QC の標準化について}

当該研究グループでは，すでに本定量的 SPECT 画像 再構成および機能画像解析プログラムを複数の施設に提 供し，施設間の一致，施設内の再現性，さらに PET と の一致について検討してきた，機器メーカーを超えた機 能画像の一致を確認する一方で, 機器の日常管理の重要 性が再認識されてきている，具体的な注意事項として以 下が挙げられる。

1）コリメータおよび検出器感度の均一性補正にかか る $\mathrm{QC}$

2 ) 撮像パラメータの確認

3 ）検査害施プロトコルの詳細管理

4）採血カウントを計測する井戸型検出器の日常管理

5）その他

特に均一性補正は日常の SPECT 撮像を行う際に最も 基本的な確認事項であり，これが保証されないと正確な 画像を撮像することができない．機器メーカーの提示す る種々の補正パラメータによって不均一な詥差は確認し にくい場合もあるが，例えば定期的に一様円筒ファント ムにおける一様性の目視によって確認するこがができる （Fig. 9A）。また, 血液放射能濃度の計測においては, Fig. 9B に示すようにエネルギーウィンドウ設定を毎回確認 することが望ましい．NaI シンチレータの場合とプラス チックシンチレータの場合で状況は異なるが, 前者の場 合には 2 つのピークの両方を含むのが理想である。プラ スチックシンチレータの場合には，カウントの閾值の設 定によって絶対感度が大きく変化することを認識してお くべきである.

\section{今後の課題}

本稿で述べた血行動態力学的な脳虚血の定量的㟝断法 は，今後多くの新規治療プロトコルの客観的評価などに
貢献することが期待されている．適切な $\mathrm{QC}$ の下であれ ば，当該研究グループの開発したプログラムパッケージ を利用することによって，正確な放射性薬剤の分布画像 を撮像することができ，さらに数理モデル解析プログラ ムを適用することで種々の生理・生化学的機能画像の定 量評価が行える，当該プログラムは臨床研究を目的に開 発されたものであり，当該研究機関との共同研究によっ て無償利用が可能である。利用にあたっては，まず QC を確認するための必要最小限のファントム実験が推奨さ れ，万一結果に不備がある場合には機器メーカーのサー ビスを受けるなどの調整作業が不可欠である。さらに， 安定した結果を得るためには, 当該研究グループの提示 する検査プロトコルに厳密に従うことも推奨される.

現在のところ IMP を使った安静時掞よび血管拡張時 の局所脳血流量画像の定量診断の際には 1 点の動脈血 採血を必要としている。これは予め求めてある標準入力 関数を較正するためである。しかし，分布体積を固定す る本法においては，採血を行わなくても絶対值の定量を 行えることが確認できている。 より詳細な精度評価を行 うことで, 無採血定量診断プロトコルの構築が今後の課 題である. IMZ についても同様に，採血を行わずに標準 入力関数のスケールを任意としても, 相対的な VT 画像, すなわち相対的な BP 画像が定量評価できることが示さ れている，相対的な欠損の診断評価のためには無採血診 断は可能である。スキャンのタイミングを含めた誤差評 価が必要である。

このような 1 回の検査で血管拡張能を定量的に評価 できる SPECT 診断法は, 糖尿病や高脂血症, 高血圧, 喫煙などの, 循環器疾患のリスク因子に基づく潜在的な 病態進行の検出に利用できる可能性が考元られる，過去 のPET を使った研究によると,リスク因子の数は冠血流 予備能と相関し，また糖尿病患者における造影上正常な 冠動脈における血流予備能の低下とアセチルコリン反応 性の低下，高血圧非合併糖尿病患者に掞ける血流予備能 の低下，無自覚無症状の糖尿病患者における血流予備能 の低下，血糖コントロールの過去数年間の平均值と血流 予供能が逆相関することなどが報告されている。多くの 臨床機関に設置されている既存の SPECT 装置を用い て, 脳・心の血管反応性や血流予備能の定量評価が実施 可能になると, PET ではできない大規模な臨床試験が実 施可能になり, 病態の調查研究や新規治療薬の効率的な 開発推進に貢献する可能性が期待される。糖尿病や高脂 血症，高血圧，喫煙などの血管病変のリスクを抱える疾 患予備軍において, 潜在的に進行している動脈硬化の早 期発見に貢献し，また治療薬有効性の客観的評価が可能 
になる。

いずれにせよ, 新規治療法の開発プロセスにおいて画 像情報を利用すること，これに基づく EBM 医療の企画 と実施は，近年米国 FDA もガイドラインを作成したと ころであり，今後の検査実施体制の整備と検証が望まれ る.SPECT はすでに多くの施設に設置された機能画像診 断装置であり, PET と同様, あるいはそれ以上の可能性 を秘める。ささらなる方法論の整備が望まれる.

\section{まとめ}

SPECT の画像診断は，当該 QSPECT プログラムパッ ケージを用いることで PET に匹敵する定量精度を確保 することが可能になった. 初回循環移行係数の高い IMP 検査に数理モデル解析を適用することで, 安静時だけで なく血管拡張後の局所脳血流量, および血管反応性を定 量評価することができる. 1 回の検査で 2 つの血流量画 像を計測することも可能であり, 血行力学的脳虚血の病 態診断への利用が可能になった。 また IMZ に対して当該 プログラムを適用することで, 残存する神経細胞の空間 的広がりと定量評価が可能になった。従来㲘念された低 血流量領域における残存分布の過小評価の問題は数理モ デル解析を適用することで解消できると考えられた。

\section{文 献}

1) Fujita $M$, Ichinose $M$, van Dyck $C H$, Zoghbi SS, Tamagnan G, Mukhin AG, Bozkurt A, Seneca N, Tipre D, DeNucci CC, Iida H, Vaupel DB, Horti AG, Koren AO, Kimes AS, London ED, Seibyl JP, Baldwin RM, Innis RB: Quantification of nicotinic acetylcholine receptors in human brain using [123I] 5-I-A-85380 SPET. Eur J Nucl Med Mol Imaging 30: 1620-1629, 2003.

2) Fujita M, Varrone A, Kim KM, Watabe H, Zoghbi SS, Seneca N, Tipre D, Seibyl JP, Innis RB, Iida H: Effect of scatter correction on the compartmental measurement of striatal and extrastriatal dopamine $\mathrm{D}_{2}$ receptors using $\left[{ }^{[23} \mathrm{I}\right]$ epidepride SPET. Eur J Nucl Med Mol Imaging 31:644654, 2004.

3) Fujita M, Ichise M, Zoghbi SS, Liow JS, Ghose S, Vines D, Sangare J, Lu JQ, Cropley VL, Iida H, Kim KM, Cohen RM, Bara-Jimenez W, Ravina B, Innis RB: Widespread decrease of nicotinic acetylchline receptors in Parkinson's disease. Ann Neurol $\quad$ 59: 174-177, 2006.

4) Hapdey S, Soret M, Ferrer L, Koulibaly P, Henriques J, Gardin I, Darcourt J, Buvat I: Quantification in SPECT: Myth or reality? A multi-centric study. Nuclear Science Symposium Conference Record, 2004 IEEE 5 : 3170-3173, 2004.

5) Iida H, Kanno I, Miura S: Rapid measurement of cerebral blood flow with positron emission tomography. Chiba Found Symp 163: 23-42, 1991.

6) Iida $\mathrm{H}$, Ito $\mathrm{H}$, Bloomfield PM, Munaka M, Higano S,
Murakami M, Inugami A, Eberl S, Aizawa Y, Kanno I, Uemura $\mathrm{K}: \mathrm{A}$ method to quantitate cerebral blood flow using a rotating gamma camera and iodine -123 iodoamphetamine with one blood sampling. Euro J Nucl Med 21: 1072-1084, 1994.

7) Iida H, Akutsu T, Endo K, Fukuda H, Inoue T, Ito H, Koga S, Komatani A, Kuwabara Y, Momose T, Nishizawa S, Odano I, Ohkubo M, Sasaki Y, Suzuki H, Tanada S, Toyama $\mathrm{H}$, Yonekura Y, Yoshida T, Uemura K : A multicenter validation of regional cerebral blood flow quantitation using [123I] iodoamphetamine and single photon emission computed tomography. J Cereb Blood Flow Metab 16: 781793, 1996.

8) Iida H, Narita $Y$, Kado H, Kashikura A, Sugawara S, Shoji Y, Kinoshita T, Ogawa T, Eberl S: Effects of scatter and attenuation correction on quantitative assessment of regional cerebral blood flow with SPECT. J Nucl Med 39: 181-189, 1998.

9) Iida $\mathrm{H}$, Eberl $\mathrm{S}$ : Quantitative assessment of regional myocardial blood flow with thallium-201 and SPECT. $J$ Nucl Cardiol 5:313-331, 1998.

10) Iida H, Shoji $Y$, Sugawara S, KinoshitaT, TamuraY, Narita $\mathrm{Y}$, Eberl S: Design and experimental validation of a quantitative myocardial ${ }^{201} \mathrm{TI}$ SPECT System. IEEE Trans Nucl Sci 46: 720-726, 1999.

11) Iida $H$, Hayashi $T$, Eberl $S$, Saji $H$ : Quantification in SPECT cardiac imaging. J Nucl Med 44: 40-42, 2003.

12) Kado $H$, Iida $H$, Miura $Y$, Narita $Y$, Ogawa $T$, Okudera $T$, Uemura $\mathrm{K}$ : Head-to-head comparison of Tc-99 $\mathrm{m} \mathrm{ECD}$ SPECT and O-15 PET in patients with chronic ischemic lesion. in Ishii Y, Yonekura Y, Fujibayashi Y, Sadato N (eds) : Recent Advances in Biomedical Imaging. Amsterdam, Elsevier, 1997, pp.195-200.

13) Kim KM, Watabe H, Hayashi T, Hayashida K, Katafuchi $T$, Enomoto N, Ogura T, Shidahara M, Takikawa S, Eberl S, Nakazawa M, Iida H: Quantitative mapping of basal and vasareactive cerebral blood flow using split-dose ${ }^{123} \mathrm{I}^{-}$ idoamphetamine and single photon emission computed tomography. NeuroImage 22:1126-1135, 2006.

14) Larsson A, Johansson L, Sundström T, Ahlström KR: A method for attenuation and scatter correction of brain SPECT based on computed tomography images. Nucl Med Commun 24: 411-420, 2003.

15) Larsson A, Johansson $L:$ Scatter-to-primary based scatter fractions for transmission-dependent convolution subtraction of SPECT images. Phys Med Biol 48: N323-N328, 2003.

16) Larsson A, Johansson L: Transmission-dependent convolution subtraction of ${ }^{99 \mathrm{~m}} \mathrm{Tc}-\mathrm{HMPAO} \mathrm{rCBF}$ SPECT $-\mathrm{A}$ Monte Carlo study. IEEE Trans Nucl Sci 52:231-237, 2005.

17) Ljungberg $M$, Larsson A, Johansson L: A new collimator simulation in SIMIND based on the Delta-Scattering technique. IEEE Trans Nucl Sci 52: 1370-1375, 2005.

18) Meikle, SR, Hutton, BF, Bailey DL: A transmissiondependent method for scatter correction in SPECT. J Nucl Med 35: 360-367, 1994.

19) Narita $Y$, Eberl S, Iida $H$, Hutton BF, Braun M, Nakamura T, Bautovich G: Monte Carlo and experimental evaluation of accuracy and noise properties of two scatter correction methods for SPECT. Phys Med Biol 41:2481-2496, 1996. 
20) Narita $Y$, Iida $H$, Eberl $S$, Nakamura $T$ : Monte Carlo evaluation of accuracy and noise properties of two scatter correction methods for $201 \mathrm{Tl}$ cardiac SPECT. IEEE Trans Nucl Sci 44:2465-2472, 1997.

要旨

SPECT を使った脳機能画像の定量化と標準化

\begin{tabular}{|c|c|c|c|c|}
\hline 溥 & 渡部 & 浩司 & 赤松 & 哲哉 \\
\hline 佳亮 & 竹内 & 朝子 & 岩田 & 倫明 \\
\hline 千晶 & 福島 & 和人 & 福本 & 真司 \\
\hline
\end{tabular}

SPECT の沉用性は高く、日常の臨床だけでなく多施設臨床評価試験での利用が期待される.しかし， 現実には SPECT の定量性は保障されておらず，施設を超えた再現性も確保できていない，当該研究 グループでは, 正確な吸収補正と散乱線補正を組み込んだ SPECT 画像再構成プログラム (QSPECT) の開発を行い，PET に匹敵する定量精度を確保した． 施設誤差を最小にする試みに基づき，初回循環 移行係数の高い IMP 検査に数理モデル解析を適用することで, 1 回の検査で安静時と血管拡張後の局 所脳血流量, 血管反応性を定量評価する方法が可能になった. 先行研究によって, 施設を超えた再現 性, 施設内での再現性, PET との一致が確認でき, 今後血行力学的脳虚血の病態診断への利用が期待 される.

\section{第 28 回 日本脳神経外科コングレス 開催のお知らせ}

会 期：2008 年 5 月 9 日（金)，10日（土），11日（日）

会 場 : パシフィコ横浜 (横浜)

会 長: 宮本 享 (国立循環器病セン夕ー脳神経外科)

連絡先 : 于 565-8565 大阪府吹田市藤白台 5-7-1 国立循環器病センター脳神経外科

¿ా 06-6833-5012 FAX 06-6836-2876

\section{主 題 : 脳神経外科の夢と志}

